\title{
ANALYSIS OF THE EFFECTIVENESS OF RETRIBUTION FOR CLEANING SERVICES AT THE ENVIRONMENTAL SERVICE OF BENGKALIS REGENCY
}

\author{
Dwi Aini ${ }^{1}$, Husni Mubarak ${ }^{2}$ \\ 1,2 Public Finance Accounting Study Program, Bengkalis State Polytechnic \\ Jl. Bathin Alam, Sungai Alam, Bengkalis, Riau, Indonesia 28711 \\ E-mail: 1dwieaenie03@gmail.com; 2husnimubarak@polbeng.ac.id
}

\begin{abstract}
Garbage/cleaning service levies are for waste/cleaning services provided or managed by the local government for individuals or entities. This study aims to determine the mechanism of retribution collection, the effectiveness of retribution for Regional Original Income (PAD), and the obstacles encountered when collecting retribution. This research was conducted at the Bengkalis Regency Environmental Service. The research object is a report on the realization of waste/cleaning retribution receipts from 2018 to 2020. This type of research uses a qualitative descriptive approach. Based on the study results, in the process of collecting retribution for the garbage/cleaning service, those who have paid the levy are given evidence of a Certificate of Regional Retribution (SKRD) in the form of a ticket from the retribution collector. At the Bengkalis Regency Environmental Service, the SKRD is divided into two types, namely daily and monthly. The sub-districts that have increased yearly are Bengkalis, Bantan, and Siak Kecil sub-districts within 3 to three years. Meanwhile, other sub-districts experienced instability in their retribution receipts. In 2018 the waste/cleaning retribution 2018 got a percentage of $89 \%$, which cannot be said to be very effective because it is still below $100 \%$ of the target achievement level. In 2019 , waste/cleaning service levy received $116 \%$, with a very effective statement. In 2020, the effectiveness of receiving retribution for waste/cleaning services in all sub-districts was at a very effective point in increasing local revenue, with an average effectiveness value of $145 \%$. Constraints in collecting user fees are that the user does not know about the existence of regulations regarding collecting payments. There are no sanctions for mandatory fees if he does not pay the user fees, the lack of supervision, the number of retribution collectors, and limited facilities and infrastructure.
\end{abstract}

Keywords: Mechanism, Effectiveness, Constraints, Service Retribution Garbage/Cleaning.

\section{INTRODUCTION}

Regional Original Revenue (Pendapatan Asli Daerah/PAD) is income earned by the region, which is collected based on statutory regulations. PAD sources come from local taxes, regional levies, and other legitimate income. Local taxes are coercive levies for Indonesian citizens. In contrast, levies are local levies as payment for services or granting specific permits provided explicitly by local governments for the benefit of individuals or entities. Retribution is one of the pads that can help problems in people's lives (Dwiastuti, 2018). The government provides services to increase regional revenues needed for development funds originating from PAD sources (Rembet et al., 2018; Saifullah et al., 2016).

One of the retributions in the Bengkalis Regency is the Garbage/Cleaning Service Retribution. Along with the rapid increase in population growth rate in Bengkalis Regency. Therefore, the local government carries out a policy to collect retribution for waste/cleaning services carried out by the Bengkalis Regency Environmental Service. Thus, there must be attention from both the government and the community in responding to how to manage the retribution for waste/cleaning services to make a good contribution to regional original revenue (Lenniawati \& Anastasia, 2020). Based on the explanation above, the problem in this research is: How is the mechanism for collecting retribution for waste/cleaning services in Bengkalis Regency? How is the effectiveness of retribution for garbage/cleaning services in the Bengkalis Regency? What obstacles arise in collecting retribution for garbage/cleaning services in Bengkalis Regency? Based on the formulation of the problem above, the purpose of this study, first to find out how the mechanism for collecting retribution 
for waste/cleaning services in Bengkalis Regency. Second to determine the effectiveness of managing retribution for waste/cleaning services in Bengkalis Regency, to find out the obstacles that arise when collecting retribution for garbage/cleaning services in Bengkalis Regency.

\section{LITERATURE REVIEW}

According to "Analysis of the Effectiveness of the Implementation of Garbage Collection in Rokan Hulu Regency" by Jufaizal (2016), the purpose of this study was to determine the effectiveness of the implementation of waste collection in Rokan Hulu Regency. The results of this study indicate that the effectiveness of the waste/cleaning retribution during the period 2011 to 2014 only reached an average of $92.08 \%$ per year. This means that the Local Government of Rokan Hulu Regency is not effective because the results of the comparison of the level of achievement are below $100 \%$, which means that the results are not effective according to the efficiency measure. "Analysis of the Implementation of Collection of Cleanliness Retribution (Study in Simpang Tiga Village, Bukit Raya District) Pekanbaru City" by Putriani \& Parjiana's (2017) was done to find out and analyze the implementation of Cleansing Retribution collection in Simpang Tiga Village, Bukit Raya District, Pekanbaru City. This study indicates that the implementation of cleaning retribution collections in Simpang Tiga Village, Bukit Raya Subdistrict, Pekanbaru City is quite implemented, seen from the implementation of cleaning retribution collections by officers to the community, which has been carried out quite well. However, there are still some obstacles, such as several people who do not want to pay the cleaning levy. In addition, the government is still less responsive in taking action because it is not firm in providing a legal basis to the relevant agencies.

\section{Effectiveness}

According to Mardiasmo (2016) in Chandra et al. (2020), effectiveness is a measure of the success or failure of an organization's goals in achieving its goals. Indicators of effectiveness describe the range of effects and impacts (outcomes) of the outputs program in achieving program objectives. The effectiveness level of retribution for waste/cleaning services can be measured using the following formula:

Effectiveness $=\frac{\text { realization of regional levy receipts }}{\text { regional retribution revenue target }} \times 100 \%$

The criteria used to assess the effectiveness of regional levies are in Table 1 below:

Table 1. Criteria for Effectiveness of Regional Retribution

\begin{tabular}{cc}
\hline Criteria for & Effectiveness Ratio (\%) \\
\hline Very Effective (VE) & $>100 \%$ \\
Effective (E) & $90 \%$ to $100 \%$ \\
Moderately Effective (ME) & $80 \%$ to $90 \%$ \\
Less Effective (LE) & $60 \%$ to $80 \%$ \\
Not Effective (NE) & $<60 \%$ \\
\hline
\end{tabular}

Source: kurnia (2020) in Mardiasmo (2016)

\section{Regional Retribution}

Based on Bengkalis Regency Regional Regulation Number 11 of 2019 concerning Amendments to Bengkalis Regency Regional Regulation Number 12 of 2011 concerning Public Service Retribution, Regional retribution, from now on referred to as retribution, is a provincial levy as payment for services or granting specific permits provided and given by the regional government for the benefit of individuals or entities. Regional levies have characteristics, namely levies are levied by local governments. In the levies, there is economic coercion, and there is a counter-achievement that can be directly appointed. Levies are imposed on every person/entity who uses the services provided. Regional levies are divided into three types, namely: 


\section{Public Service Retribution}

Objects for public service levies are services provided or provided by local governments for public interest and benefit and can be enjoyed by individuals or entities. The subject of the Public Service Retribution is an individual or entity that uses/wants the public service concerned. Types of public service levies based on Law No. 28 of 2009 are health service levies, garbage/cleaning services levies, levies for replacing ID cards and civil registration deed, funeral services levies and cremation of corpses, levies for parking services on public roads, market service levies, Motor vehicle testing levies, fire extinguisher inspection fees, map printing fees, latrine supply, and suction fees, liquid waste management fees, re-calibration service fees, education service fees, telecommunication tower control fees.

\section{Business Services Retribution}

Objects for Business Services Retribution are services the Regional Government provides by adhering to commercial principles. Including services by using/utilizing regional assets that have not been used optimally and services by regional governments as long as they have not been provided adequately to the private sector. Types of business service levies are levies for the use of regional assets, levies, levies for wholesale markets and shops, levies for auction sites, levies for terminals, levies for unique parking spaces, levies for lodging/villa, levies for slaughterhouses, levies for port services, levies for places recreation and sports, levies on water crossings, levies on sales of regional business production.

\section{Certain Licensing}

Retribution Specific Licensing Retribution is a levy on certain licensing services by local governments to individuals or entities intended to regulate and supervise activities on space utilization, use of natural resources, goods, infrastructure, facilities, or certain facilities to protect the public interest and maintain the environmental sustainability. Certain types of Licensing Retribution are levies for building permits, levies for permits for selling alcoholic beverages, nuisance permits levies, levies for route permits, levies for fishery business permits, levies for extending permits to employ foreign workers.

\section{Retribution for Waste/Cleaning Services}

The object of Retribution for Waste/Cleaning Services as referred to in Article 110 paragraph (1) letter b of Law no. 28 of 2009 is a waste/cleaning service organized by the Regional Government, which consists of providing a location for disposal or final disposal of waste, taking or collecting waste from its source to a temporary disposal site, transporting waste from its source and/or a temporary disposal location to a final waste disposal location. The subject of the levy is an individual or entity that uses/enjoys waste/cleanliness services. Mandatory levies must pay a levy when using waste/cleaning services. The tariff for the waste/cleaning service retribution for the Bengkalis Regency Environmental Service is regulated in the Bengkalis Regency in line with Regional Regulation Number 11 of 2019 concerning Public Service Retribution.

\section{METHODOLOGY}

This research was conducted at the Bengkalis Regency Environment Agency. The object of this research is the Report on the Realization of Retribution for Waste/Cleaning Services for 2018 to 2020. Data collection techniques use observations, interviews, and documentation for analysis. The data analysis method is data reduction, data presentation, and conclusion drawing. This type of research used a qualitative method with a descriptive approach. 


\section{RESULTS AND DISCUSSION}

\section{The Mechanism of Collecting Retribution for Waste Services/Cleaning}

The Environmental Services has 7 units of Technical Service Units (UPT), namely UPT Bengkalis, UPT Bantan, UPT Bukit Batu, UPT Siak Kecil, UPT Mandau, UPT Pinggir and UPT Laboratories. The mechanism for collecting retribution for waste/cleaning services is that the collection officer takes the Regional Levies Determination Letter to the Recipient Treasurer of the Bengkalis Regency Environmental Service. The Regional Levies Determination Letter provided at the Department of Environment (DLH) is in the form of a ticket. The collection officer collects the required retribution using the SKRD (Surat Ketetapan Retribusi Daerah). The retribution collection officer then deposits the retribution collection results to the recipient's assistant treasurer. The assistant treasurer of the recipient receives the results of the levy from the collection officer and recaps the collection results. The assistant treasurer of the recipient shall deposit the recapitulation of the levy results to the recipient treasurer. Furthermore, the revenue treasurer deposits the waste/cleaning service retribution results to the Regional Asset Financial Management Agency (BPKAD) through a designated bank account. In the process of collecting retribution for waste/cleaning services, those who have paid the levy will be given proof of payment in the form of a ticket.

\section{Effectiveness of Receiving Retribution for Waste/Cleaning Services}

Below are presented data on targets and realization of retribution for waste/cleaning services in Bengkalis Regency from 2018 to 2020.

Table 1. Target and Realization of Retribution for Waste/Cleaning Services

\begin{tabular}{lrrrrrr}
\hline \multirow{2}{*}{$\begin{array}{c}\text { Districts } \\
\text { (000) }\end{array}$} & \multicolumn{2}{c}{ 2018 } & \multicolumn{2}{c}{ 2019 } & \multicolumn{2}{c}{ 2020 } \\
\cline { 2 - 7 } & \multicolumn{1}{c}{ Target } & Realization & \multicolumn{1}{c}{ Target } & Realization & Target & Realization \\
\hline Bengkalis & 215.000 & 171,246 & 215,000 & 204,551 & 172,000 & 234.546 \\
Bantan & 25.000 & 21.275 & 25.000 & 25.650 & 20.000 & 42.475 \\
Bukit Batu & 85.000 & 54.440 & 85.000 & 40.570 & 68.000 & 102.195 \\
Siak Kecil & 20.000 & 21.720 & 20.000 & 22.000 & 16.000 & 34.120 \\
Monday & 555.000 & 533.365 & 555.000 & 19.940 & 444.000 & 627.854 \\
Pinggir & 75.000 & 72.460 & 75.000 & 745.700 & 60.000 & 83.535 \\
Rupert & 25.000 & 14.980 & 25.000 & 101.580 & 20.000 & 36.710 \\
Amount & 1.000 .000 & 889.486 & 1.000 .000 & 1.159 .991 & 800.000 & 1.161 .435 \\
\hline
\end{tabular}

As can be seen in the table of targets and the realization of the Waste/Cleaning Service Charges from 2018 to 2020, the number of receipts for the waste/cleaning retribution each year has increased and decreased with the budgeted targets. The effectiveness of regional retribution is a value calculated based on the percentage comparison of the realization of regional retribution revenues with regional revenue targets. The higher the level of effectiveness obtained, the better the ability of the environmental service of Bengkalis Regency to achieve its target. Vice versa, the lower or the smaller the level of effectiveness reached; the performance of the garbage collection/cleaning retribution apparatus is less than optimal. Table 2 are presented the effectiveness retribution waste services/hygiene per year.

Based on the data of Table 2 described the decision effectiveness levy waste services/cleanliness of the year in 2018, only 1 (one) sub-district received the Very Effective (SE) information, namely Siak Kecil District. The results of effective because the realization exceeded what was targeted where the target retribution was Rp. $20,000,000$ realized Rp. $21,720,000$ with a percentage of $109 \%$. 
Overall, the waste/cleaning levy in 2018 has a percentage of $89 \%$, and it cannot be said to be very effective because it is still below $100 \%$ of the target achievement level.

Table 2. Effectiveness Revenue Service Fees Waste/Cleaning Bengkalis 2018

\begin{tabular}{lrrrc}
\hline \multirow{2}{*}{ Districts } & \multicolumn{2}{c}{2018} & \multirow{2}{*}{ Effectiveness } & \multirow{2}{*}{ Note } \\
\cline { 2 - 4 } & \multicolumn{1}{c}{ Target } & Realization & & \\
\hline Bengkalis & 215.000 & 171.246 & $79.65 \%$ & LE \\
Bantan & 25.000 & 21.275 & $85.10 \%$ & ME \\
Bukit Batu & 85.000 & 54.440 & $64.05 \%$ & LE \\
Siak Kecil & 20.000 & 21.720 & $108.60 \%$ & VE \\
Mandan & 555.000 & 533.365 & $96.10 \%$ & $\mathrm{E}$ \\
Pinggir & 75.000 & 72.460 & $96.61 \%$ & $\mathrm{E}$ \\
Rupert & 25.000 & 14.980 & $59.92 \%$ & $\mathrm{NE}$ \\
Amount & 1.000 .000 & 889.486 & $88.95 \%$ & $\mathrm{ME}$ \\
\hline
\end{tabular}

Table 3. Effectiveness Revenue Service Fees Waste/Cleaning Bengkalis 2019

\begin{tabular}{lrrrc}
\hline \multirow{2}{*}{ Districts } & \multicolumn{2}{c}{2019} & \multirow{2}{*}{ Effectiveness } & \multirow{2}{*}{ Note } \\
\cline { 2 - 4 } & \multicolumn{1}{c}{ Target } & Realization & & \\
\hline Bengkalis & 215.000 & 204.551 & $95.14 \%$ & $\mathrm{E}$ \\
Bantan & 25.000 & 25.650 & $102.60 \%$ & $\mathrm{VE}$ \\
Bukit Batu & 85.000 & 40.570 & $47.73 \%$ & $\mathrm{NE}$ \\
Siak Kecil & 20.000 & 22.000 & $110.00 \%$ & $\mathrm{VE}$ \\
Monday & 555.000 & 19.940 & $3.59 \%$ & $\mathrm{NE}$ \\
Pinggir & 75.000 & 745.700 & $994.27 \%$ & $\mathrm{VE}$ \\
Rupert & 25.000 & 101.580 & $406.32 \%$ & $\mathrm{VE}$ \\
Amount & 1.000 .000 & 1.159 .991 & $116.00 \%$ & VE \\
\hline
\end{tabular}

In 2019 the Regional Government of the Bengkalis Regency Environmental Service set the target for retribution revenue per sub-district to remain the same as in 2018. Overall, the effectiveness of waste/cleanliness fees in 2019 experienced better changes than the previous year. The sub-districts that received information were very effective because each sub-district could take advantage of the existing potential well. The sub-district realized the retribution that was appropriately budgeted. The sub-districts that received ineffective information, such as Bukit Batu and Mandau sub-districts, were only around $48 \%$ and $4 \%$. Overall, the waste/cleaning service levy in 2019 received a percentage of $116 \%$ and was said to be very effective because it was more than $100 \%$.

Table 4. Effectiveness Revenue Service Fees Waste/Cleaning Bengkalis 2020

\begin{tabular}{lrrrl}
\hline \multirow{2}{*}{ Districts } & \multicolumn{2}{c}{ 2020 } & \multirow{2}{*}{ Effectiveness } & \multirow{2}{*}{ Note } \\
\cline { 2 - 3 } & \multicolumn{1}{c}{ Target } & Realization & & \\
\hline Bengkalis & 172.000 & 234.546 & $136.36 \%$ & VE \\
Bantan & 20.000 & 42.475 & $212.38 \%$ & VE \\
Bukit Batu & 68.000 & 102.195 & $150.29 \%$ & VE \\
Siak Kecil & 16.000 & 34.120 & $213.25 \%$ & VE \\
Monday & 444.000 & 627.854 & $141.41 \%$ & VE \\
Pinggir & 60.000 & 83.535 & $139.23 \%$ & VE \\
Rupert & 20.000 & 36.710 & $183.55 \%$ & VE \\
Amount & 800.000 & 1.161 .435 & $145.18 \%$ & VE \\
\hline
\end{tabular}


In 2020, receiving retribution for waste/cleaning services in all sub-districts was very effective in increasing local revenue, with an average effectiveness value of $145 \%$. This shows that the performance of the Bengkalis Regency Environmental Service is quite good because, in 2020, the desired target is always realized following what has been targeted. Therefore, the realization of retribution for waste/cleaning services in 2020 can be a target for 2021.

Collection of Retribution for Garbage in the Regency Bengkalis has obstacles. Namely, the mandatory retribution does not yet know the existence of regulations regarding the collection of fees. In addition, there are no sanctions for mandatory levies if they do not pay the levy, lack of supervision, and the number of retribution collectors limited facilities and infrastructure.

\section{CONCLUSION AND RECOMMENDATIONS}

Based on the research and analysis results, it can be concluded that in collecting the retribution for the garbage/cleaning service, those who have paid the levy are given proof of an SKRD in the form of a ticket from the levy-collecting officer. At the Bengkalis Regency Environmental Service, the SKRD is divided into two types, namely daily and monthly. In 2018, the overall level of effectiveness in receiving the waste/cleaning retribution was still quite effective, with the percentage of effectiveness reaching $89 \%$. In 2019 the effectiveness of the waste/cleaning service levy reached $115.9 \%$ with very effective information, and in 2020 the waste/cleaning service levy increased from 2019 and 2018, which was $145.1 \%$ with very effective information. Constraints in the process of collecting retribution for waste/cleaning are mandatory retribution, not knowing the existence of regulations regarding retribution collection, no sanctions for retribution if not paying the levy, lack of supervision, and the number of retribution collectors and limited facilities and infrastructure.

With this research, it is hoped that it can help solve the problem of retribution for waste/cleaning services. For further study, it is expected to increase the number of samples, discuss all regional retributions, not only focusing on one levy and how much influence or participation the acceptance of the waste/cleaning service retribution has on Regional Original Income.

\section{REFERENCES}

Bengkalis District Regulation No. 11 of 2019 Regarding "Public Service Levies".

Chandra, C.A., Sabijono, H., \& Runtu, T. (2020). Efektivitas dan Kontribusi Penerimaan Pajak Bumi dan Bangunan Perdesaan dan Perkotaan (PBB-P2) terhadap Penerimaan Pendapatan Asli Daerah (PAD) di Kota Gorontalo Tahun 2016-2018. Jurnal Riset Akuntansi 15(3), 290-298.

Dwiastuti, N. (2018). Efektifitas Penerimaan Retribusi Daerah terhadap Pendapatan Asli Daerah Kabupaten/Kota di Provinsi Kalimantan Barat. Prosiding SATIESP 2018. February Tanjungpura University.

Jufaizal (2016). Analisis Efektivitas Pelaksanaan Pemungutan Retribusi Sampah di Kabupaten Rokan Hulu. Jurnal Mahasiswa Prodi Manajemen UPP, 3(2).

Law of the Republic of Indonesia Number 23 of 2014 concerning Local Government.

Law of the Republic of Indonesia Number 28 of 2009 concerning Regional Taxes and Levies.

Lenniawati, M., \& Anastasia, N. (2020). The Influence of Cashless Payment Usage and Protection Against Financial Inclusion in Micro and Small Enterprises in Kediri. International Journal of Financial and Investment Studies, 1(2), 67-76. https://doi.org/10.9744/ijfis.1.2.67-76

Putriani, D., \& Parjiyana, P. (2017). Analysis of the Implementation of Collection of Cleanliness Retribution (Study in Simpang Tiga Village, Bukit Raya District) Pekanbaru City. Publika: Jurnal Ilmu Administrasi Publik, 3(1), 42-65.

Rembet, J.E., Tinangon, J.J., \& Runtu, T. (2018). Analisis Efektifitas Penagihan Retribusi Persampahan dan Kontribusinya terhadap Pendapatan Asli Daerah Kota Tomohon. Jurnal Riset Akuntansi Going Concern, 13(4), 530-536.

Saifullah, Anwar, \&Marlina. (2016). The Effectiveness of Increasing Waste Retribution on Achieving Regional Original Income in Banda Aceh City. Serambi Akademia. Jurnal Pendidikan, Sains dan Humaniora, 4(2), 96-103. 